\title{
STK11 wt Allele
}

National Cancer Institute

\section{Source}

National Cancer Institute. STK11 wt Allele. NCI Thesaurus. Code C51322.

Human ST K11 wild-type allele is located in the vicinity of 19p13.3 and is approximately 23 $\mathrm{kb}$ in length. This allele, which encodes serine/threonine-protein kinase ST K11 protein, is involved in cell cycle arrest at the G1 checkpoint and regulation of cell polarity. Certain allelic variants of the ST K11 gene cause Peutz-Jeghers syndrome, a hereditary disease characterized by predisposition to benign and malignant tumors of many organ systems. 